\title{
The enhancement methods for the degradation of TCE by zero-valent metals
}

\author{
Shu-Fen Cheng *, Shian-Chee Wu \\ Graduate Institute of Environmental Engineering, National Taiwan University, Taipei, Taiwan, ROC
}

Received 25 August 1999; accepted 3 November 1999

\begin{abstract}
Batch tests were performed to compare the degradation rates of TCE on $\mathrm{Fe}^{0}$ and $\mathrm{Zn}^{0}$. Our results indicated that the degradating capability of $\mathrm{Zn}^{0}$ to TCE was nearly 10 times higher than that of $\mathrm{Fe}^{0}$. On the other hand, the degradation rates of $\mathrm{Fe}^{0}$ or $\mathrm{Zn}^{0}$ in conjunction with other metals for reduction of TCE was investigated. The selected metals were nickel $\left(\mathrm{Ni}^{0}\right)$ and palladium $\left(\mathrm{Pd}^{0}\right)$ both of which have a strong enhancement effect. The reduction rates of $\mathrm{Zn}^{0} / \mathrm{Pd}^{0}$ and $\mathrm{Zn}^{0} / \mathrm{Ni}^{0}$ for TCE were the fastest. $\mathrm{Fe}^{0}$ that had lost its surface activity could be activated again by the addition of $\mathrm{Pd}^{0}$ or $\mathrm{Ni}^{0}$. () 2000 Elsevier Science Ltd. All rights reserved.
\end{abstract}

Keywords: Chlorinated organic compound; Zero-valent metal; Bimetallics; Chloroethylene

\section{Introduction}

In Taiwan, chlorinated organic compounds, such as PCE, TCE, $\mathrm{CCl}_{4}, \mathrm{CHCl}_{3}$ and $\mathrm{CH}_{2} \mathrm{Cl}_{2}$, are widely used in industry. They are mainly used as solvents in degreasing, washing, extraction, foaming, spraying and manufacturing, etc. In recent years, the underground water of many sites in Taiwan has been heavily contaminated by chlorinated organic compounds. For example, the RCA site in Taoyuan is contaminated by PCE and TCE, the Philips site in Hsinchu is contaminated by PCE, and the An-Shuenn site in Tainan is contaminated by pentachlorophenol (PCP). There is, therefore, considerable interest in the remediation technique of sites contaminated by chlorinated organic compounds. The reduction power of zero-valent iron to chlorinated organic compounds has been a focus of investigation in recent years among the techniques that are used in the remediation of sites contaminated by chlorinated organic compounds

\footnotetext{
* Corresponding author.

E-mail address: d4541004@ms.cc.ntu.edu.tw (S.-F. Cheng).
}

(Matheson and Tratnyek, 1994; Gillham and Stephanie, 1994; Smyth et al., 1995; Orth and Gillham, 1996; Agrawal and Tratnyek, 1996; Weber, 1996; O'Hannesin and Gillham, 1998).

The research on the zero-valent iron technique in recent years has shown that zero-valent iron has many drawbacks in practical applications. Firstly, after a short period of reactions zero-valent iron is liable to form an oxide film on the surface, which subsequently reduces the reaction activity (Wang and Zhang, 1997). Secondly, the retention of the surface activity of zero-valent iron is difficult to maintain. Once $\mathrm{Fe}^{0}$ is in contact with air, even under proper storage, its reactivity towards chlorinated organic compounds is inevitably reduced (Cheng and $\mathrm{Wu}, 1998)$. Thirdly, there is considerable variation in the reactivity towards chlorinated organic compounds of $\mathrm{Fe}^{0}$ of different origins. The reaction rates can differ by up to three orders of magnitude ( $\mathrm{Su}$ and Puls, 1999). Matheson and Tratnyek (1994) proposed that if $\mathrm{Fe}^{0}$ received an $\mathrm{HCl}$ acid washing process prior to its use, this could increase the surface reaction activity. However, according to the research of Su and Puls (1999) on the effects of the acid prewashing and our previous research results, the acid-washing process not only tends 
to cause many fine particles of $\mathrm{Fe}^{0}$ powder to be lost, but also causes the $\mathrm{Fe}^{0}$ to have a faster oxidation rate in the processes of washing and drying. The above factors cause the zero-valent iron technique to be largely restricted in its application to in situ remediation.

In recent years, a great deal of research has concentrated on the improvement of the zero-valent iron technique. This research has included the use of ultrasonic oscillation to remove the oxide film on the $\mathrm{Fe}^{0}$ surface (Ruiz et al., 1998), the use of external voltage to maintain the surface activity of $\mathrm{Fe}^{0}$ (Cheng and $\mathrm{Wu}$, 1998), the use of the bimetallics technique (Appleton, 1996; Siantar et al., 1996), the use of palladized iron (Muftikian et al., 1995) and the use of synthesized nanoscale palladized iron (Wang and Zhang, 1997), etc.

Matheson and Tratnyek (1994) proposed three pathways for the reduction dechlorination reactions of $\mathrm{Fe}^{0}$ to chlorinated organic compounds: (1) to direct electrons transfer from iron metal at the metal surface; (2) to catalyze hydrogenolysis by the $\mathrm{H}_{2}$ that is formed by reduction of $\mathrm{H}_{2} \mathrm{O}$ during anaerobic corrosion; (3) to reduction by the $\mathrm{Fe}^{+2}$, which results from corrosion of the metal. From the viewpoint of electrochemical theory, the first pathway means that a metal with a stronger reducing power is advantageous to the dechlorination reactions of the chlorinated organic compounds. According to electrochemical corrosion theory, in an oxygen-free $\mathrm{Zn}-\mathrm{H}_{2} \mathrm{O}$ or $\mathrm{Fe}-\mathrm{H}_{2} \mathrm{O}$ system containing $\mathrm{H}^{+}$, the surface of the metal (such as $\mathrm{Zn}^{0}$ ) will generate the following reaction:

$\mathrm{Zn}^{0}+2 \mathrm{H}^{+} \rightarrow \mathrm{Zn}^{+2}+\mathrm{H}_{2} \uparrow$

According to electrolysis chemical theory, the reduction power of a cathode in an electrolysis system is mainly derived from the function of hydrogen atoms. Once the hydrogen atoms, through the reaction of $\mathrm{H}+\mathrm{H} \rightarrow \mathrm{H}_{2} \uparrow$, combine together and form a hydrogen gas in a bubble form, they no longer participate in the reduction reaction. Furthermore, the accumulation of $\mathrm{H}_{2}$ gas bubbles on the metal surface will hinder the progress of the reaction (Matheson and Tratnyek, 1994; Ballapragada et al., 1997). Due to the different characteristics of metals, the formation rate of hydrogen gas on the surface of each metal varies; this is called the hydrogen overvoltage of the metal. The second pathway means that a metal with a higher hydrogen overvoltage is advantageous to the reduction of the chlorinated organic compounds. The reduction potential of $\mathrm{Zn}^{0}$ is stronger than that of $\mathrm{Fe}^{0}$, and $\mathrm{Zn}^{0}$ is a metal with a high hydrogen overvoltage, second only to that of mercury. Hence, from the above two points of view, $\mathrm{Zn}^{0}$ should be the better selection in degradation of chlorinated organic compounds.

Recent studies pointed out that where zero-valent iron was used in conjunction with another metal for the degradation of chlorinated organic compounds, the second metal primarily has the following functions: (1) as a catalyst (Wang and Zhang, 1997), (2) preventing the formation of the oxide film on the surface of $\mathrm{Fe}^{0}$ (Wang and Zhang, 1997), and (3) inducing $\mathrm{Fe}^{0}$ to release electrons at a faster rate due to the difference of electric potentials between $\mathrm{Fe}^{0}$ and the second metal to reduce the chlorinated organic compounds (Gavaskar et al., 1998). Appleton (1996) proposed that nickel has the effect of accelerating the degradation of TCE by $\mathrm{Fe}^{0}$. Wang and Zhang (1997) synthesized nanoscale palladized iron to degradation of TCE and PCBs. Muftikian et al. (1995) used palladized iron to reduction of $\mathrm{CCl}_{4}$ and TCE. All these studies showed a significant promotional effect.

The objectives of our study were to: (1) compare the degradation rates of different $\mathrm{Fe}^{0}$ and $\mathrm{Zn}^{0}$ to TCE in order to further evaluate the feasibility of using $\mathrm{Zn}^{0}$ to replace $\mathrm{Fe}^{0}$; (2) investigate the promotional effects of a combination $\mathrm{Fe}^{0}$ or $\mathrm{Zn}^{0}$ with a second metal $\mathrm{Ni}^{0}$ or $\mathrm{Pd}^{0}$ for degradation of TCE.

\section{Experimental}

\subsection{Chemicals and materials}

Chlorinated compound, trichloroethylene (TCE) was obtained from Merck (99.5+\%, GR grade). TCE stock solution was prepared by weighting $0.0695 \mathrm{~g}$ of pure TCE solvent to dissolve in $100 \mathrm{ml}$ of methanol. Methanol was obtained from Acros (99.8+\%, PA grade). TCE aqueous solutions were made by diluting the stock solution with Milli-Q water. The Milli-Q water was sparged with Argon gas.

Two kinds of iron were used: one was obtained from Riedel-deHaen, powdered $\mathrm{Fe}^{0}(99+\%$, RG, made by reduction), the other was obtained from Aldrich, granular $\mathrm{Fe}^{0}$ (10-40 mesh, 99.999\%, stored under nitrogen). Zincs were obtained from three different companies: Aldrich granular $\mathrm{Zn}^{0}(-10+50$ mesh, 99.8\%, ACS reagent), Acros granular $\mathrm{Zn}^{0}$ (30 mesh, $99.7 \%$, PA grade), and Hanawa powdered $\mathrm{Zn}^{0}(90.0 \%$, guaranteed reagent). Nickel was obtained from Aldrich powdered $\mathrm{Ni}^{0}$ (-100 mesh, 99.99\%). Palladium was obtained from Acros powdered $\mathrm{Pd}^{0}$ (99.99\%, ACS reagent).

\subsection{Experimental methods}

Batch tests were conducted to investigate the degradation of TCE. TCE aqueous solutions were prepared by diluting the stock solution with Ar-sparged Milli-Q

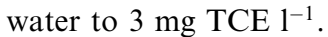




\subsection{Single metal tests}

Three grams of each metal $\left(\mathrm{Fe}^{0}, \mathrm{Zn}^{0}, \mathrm{Ni}^{0}\right)$ were added to each brown serum vial (with measured internal volumes of $15 \mathrm{ml}$ ). Each vial was filled with TCE aqueous solution with no headspace, and was then sealed immediately with aluminum crimp caps with Teflon faced septum. For each test, 10 vials containing TCE and metal and 10 controls containing TCE only were prepared for different reaction times. All the vials were put on a shaker (oscillated frequency $130 \mathrm{rpm}$, at $25^{\circ} \mathrm{C}$ ). At each sampling time, $5 \mathrm{ml}$ of subsamples were transferred via a syringe from the sample to the other clean vials, and then were sealed immediately with aluminum crimp caps with Teflon faced septum. Before analysis, all the subsamples were stored in the oven (set at $25^{\circ} \mathrm{C}$ ) for more than $0.5 \mathrm{~h}$ to let the TCE reach the equilibrium between the headspace and the aqueous phase.

\subsection{Bimetallics tests}

For the combination-with-palladium tests, $50 \mathrm{mg}$ of palladium and $3 \mathrm{~g}$ of tested metal were added to each vial. For the combination with nickel tests, $3 \mathrm{~g}$ of nickel and $3 \mathrm{~g}$ of tested metal were added to each vial. The remaining steps were the same as for the single metal tests.

\subsection{Analytical methods}

The concentrations of TCE and its chlorinated products were determined by using the gas chromatography headspace equilibration method. For each sample, $5 \mu$ of the headspace gas was taken by using a glass gas syringe, and then was injected into the chromatograph.

Analyses for TCE and its chlorinated products were conducted using a 5890II Hewlett Packard gas chromatograph equipped with a $30 \mathrm{~m} \times 0.53 \mathrm{~mm}$ (ID) $\times$ $3.0 \mu \mathrm{m}$ (thickness), DB624 analytical column (J \& W) and an electron capture detector (ECD). The temperature was set as follows: oven temperature: $60^{\circ} \mathrm{C}$, injection port temperature: $220^{\circ} \mathrm{C}$, detector temperature: $250^{\circ} \mathrm{C}$. Nitrogen was used as the carrier gas at a flow rate of about $4.5 \mathrm{ml} / \mathrm{min}$. The method detection limit (MDL) for TCE was $0.005 \mathrm{mg} / \mathrm{l}$.

\section{Results and discussion}

\subsection{The effects of $\mathrm{Fe}^{0}$ characteristics}

Many research results lead to an unanimous conclusion that the degradation rate of $\mathrm{Fe}^{0}$ to the chlorinated organic compounds is influenced by the magnitude of the "clean specific surface area" of zerovalent iron (Matheson and Tratnyek, 1994; Weber, 1996). In the past, most studies emphasized the study of the effect of the specific surface area of $\mathrm{Fe}^{0}$. However, according to this research and recent research results (Cheng and Wu, 1998; Su and Puls, 1999), the influence of "cleanness" on the reaction rate is much greater than the influence of the magnitude of the specific surface area of $\mathrm{Fe}^{0}$. The source, quality, purity and freshness of $\mathrm{Fe}^{0}$ have a significant influence on the reaction rate. This research used two types of $\mathrm{Fe}^{0}$ of different sources, different particle sizes, and different unsealed time. One was a granular iron of 10-40 mesh, produced by Aldrich, with a purity of $99.999 \%$, stored in $\mathrm{N}_{2}$, and never unsealed prior to its use. The other was a powdered iron, produced by Riedel-deHaen, with a purity of $99 \%$, made by reduction, and unsealed for a few months under proper sealing and storage and showing no oxidation. The research results showed that the Riedel-deHaen powdered $\mathrm{Fe}^{0}$ has almost no promotional effect on the degradation of TCE after nearly $250 \mathrm{~h}$ of reaction, as shown in Fig. 1. On the other hand, the Aldrich granular $\mathrm{Fe}^{0}$ has a significant effect. Under the system used in our research, the degradation reaction of TCE indicated a half-life of $239 \mathrm{~h}$, about 10 days.

Although the magnitude of the specific surface area of $\mathrm{Fe}^{0}$ is proportional to the degradation rate of TCE, the purity and the freshness of $\mathrm{Fe}^{0}$ affect whether or not the degradation of TCE proceeds. In our past study, the Riedel-deHaen powdered $\mathrm{Fe}^{0}$ that was used in this research had been used in experiments on the reduction of $\mathrm{CCl}_{4}$ and $\mathrm{CHCl}_{3}$ (Cheng and $\mathrm{Wu}, 1998$ ). During the initial stage of unsealing, it has a conspicuous promotional effect on the degradation of $\mathrm{CCl}_{4}$ and $\mathrm{CHCl}_{3}$. Meanwhile, the powdered $\mathrm{Fe}^{0}$ (325 mesh, purity 97\%, hydrogen reduced, Cat. No. 20930-9) was obtained from Aldrich was used in the same tests; after more than $100 \mathrm{~h}$ of test, there were no indication of any promotional

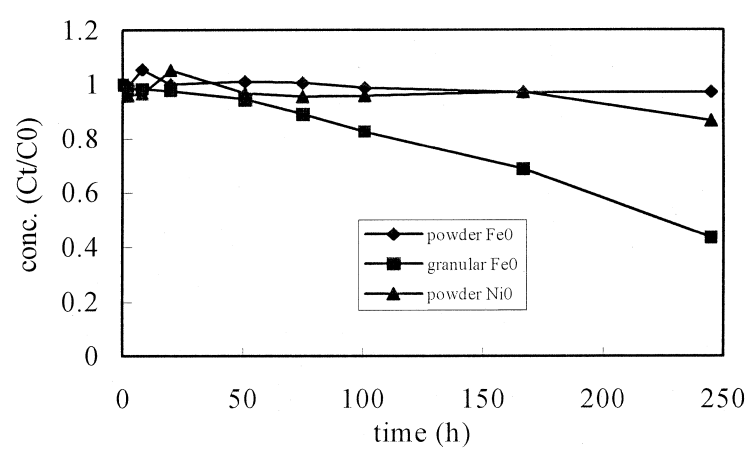

Fig. 1. TCE degradation by using $\mathrm{Fe}^{0}$ and $\mathrm{Ni}^{0}$. Conditions: batch tests were performed by using $3 \mathrm{~g}$ of $\mathrm{Fe}^{0}$ or $\mathrm{Ni}^{0}$ in serum vials ( $15 \mathrm{ml}$ by volume) in contact with $3 \mathrm{mg} \mathrm{TCE} 1^{-1}$ solution at $25^{\circ} \mathrm{C}$, and mixed with the shaker at $130 \mathrm{rpm}$. 
effect by the Aldrich $\mathrm{Fe}^{0}$ on the degradation of $\mathrm{CCl}_{4}$. Su and Puls (1999) also used the same $\mathrm{Fe}^{0}$ in the degradation tests of TCE. Their results indicated that the reaction rate thereof can differ from that of $\mathrm{Fe}^{0}$ from other manufacturers by up to three orders of magnitude.

Matheson and Tratnyek (1994) proposed that subjecting $\mathrm{Fe}^{0}$ to an acid washing of $\mathrm{HCl}$ aqueous prior to reaction can remove the oxide film on the surface of iron, thereby increasing the available reactive sites and increasing the rate of the degradation. However, our research indicated that iron washed by aqueous $\mathrm{HCl}$ was oxidized into brown oxide at a high speed upon coming into contact with air during the washing, rinsing and drying processes. The acid washing of aqueous $\mathrm{HCl}$ in this way not only causes many fine $\mathrm{Fe}^{0}$ particles to be lost, but also accelerated the oxidation rate of $\mathrm{Fe}^{0}$. The research on the $\mathrm{HCl}$ pretreatment effects done by $\mathrm{Su}$ and Puls (1999) also indicated that the acid pretreatment processes may have generated more non-reactive sites relative to the reactive sites, and caused a decrease in the reaction rate constant. Therefore, acid prewashing may not be an effective and convenient method for improving the drawbacks of $\mathrm{Fe}^{0}$ unless the contact of iron surfaces with air can be completely avoided.

\subsection{TCE degradation by $\mathrm{Zn}^{0}$}

With electrochemical theory, not only can the degradation mechanism proposed by Matheson and Tratnyek be explained, but also $\mathrm{Zn}^{0}$ can be considered to be the best metal in reduction of chlorinated organic compounds. For the first pathway in which the metal is directly used for reduction of the chlorinated organic compounds (Matheson and Tratnyek, 1994; Vogel et al., 1987; Criddle and McCarty, 1991; Gold et al., 1997; Roberts et al., 1996), the standard reduction potential of iron is $-0.44 \mathrm{~V}$, and the standard reduction potential of zinc is $-0.763 \mathrm{~V}$. Conspicuously, zinc more easily releases an electron to reduce the chlorinated organic compounds than iron does. The second pathway can be explained in greater detail by using the electrochemical theory. Metals with a higher hydrogen voltage are less liable to form hydrogen gas in the system. Therefore, most hydrogen exists in the atomic state, thereby generating a strong reduction potential. In the second pathway, $\mathrm{H}_{2}$ designates hydrogen in its atomic state, and a metal with a high hydrogen overvoltage shall be the best selection of a catalyst. $\mathrm{Zn}^{0}$ has a hydrogen overvoltage of $0.7 \mathrm{~V}$, which is a metal with the second highest hydrogen overvoltage, second only to mercury. For the above two reaction pathways, $\mathrm{Zn}^{0}$ not only can be used as a strong reducing agent, but also as a good catalyst.

This research used $\mathrm{Zn}^{0}$ from different sources, with different particle sizes and different purities, to carry out the degradation tests on TCE, in order to study the feasibility of using $\mathrm{Zn}^{0}$ for remediation of sites con- taminated by chlorinated organic compounds. The research results indicated that the degradation reaction of $\mathrm{Zn}^{0}$ to TCE approximates to a first-order degradation reaction model $\left(R^{2}>0.99\right)$. The reaction rate thereof can be shown by the following equation:

$\frac{C_{t}}{C_{0}}=\mathrm{e}^{-k t}$

where $C_{0}$ is the initial TCE concentration $(\mathrm{mg} / \mathrm{l}), C_{t}$ the TCE concentration $(\mathrm{mg} / \mathrm{l})$ at a reaction time $t(\mathrm{~h})$, and $k$ is the degradation rate constant $\left(\mathrm{h}^{-1}\right)$. The research results are shown in Fig. 2. The Hanawa powdered $\mathrm{Zn}^{0}$ has a degradation rate constant, $k$, of $0.0278\left(\mathrm{~h}^{-1}\right)$ and a half-life, $t_{1 / 2}$, of $26.8 \mathrm{~h}$. The Aldrich granular $\mathrm{Zn}^{0}$ has a degradation rate constant, $k$, of $0.013\left(\mathrm{~h}^{-1}\right)$ and a halflife of $56.8 \mathrm{~h}$. The Acros granular $\mathrm{Zn}^{0}$ forms a degradation reaction to TCE less conspicuous than that of the previous two $\mathrm{Zn}^{0}$. Among the three kinds of $\mathrm{Zn}^{0}$, the Aldrich granular $\mathrm{Zn}^{0}$ reagent has been unsealed for more than one year, and yet the degradation rate thereof to TCE was quite fast in comparison with other $\mathrm{Zn}^{0}$. Therefore, the activity of $\mathrm{Zn}^{0}$ lasted longer and the decreasing rate of the surface activity was slower than that of iron. In other words, the storage method of $\mathrm{Zn}^{0}$ is easier than $\mathrm{Fe}^{0}$ when used in a remediation technique. Table 1 lists the half-lives for TCE degradation by $\mathrm{Fe}^{0}$, $\mathrm{Zn}^{0}, \mathrm{Ni}^{0}$ and bimetallics.

In the degradation tests of $\mathrm{Zn}^{0}$ to TCE, this research also investigated the influence of the amount of $\mathrm{Zn}^{0}$ added on the reaction rate. Three grams and $5 \mathrm{~g}$ of Aldrich granular $\mathrm{Zn}^{0}$, respectively, were separately added into $15 \mathrm{ml}$ of aqueous TCE. The results indicated that the run with $3 \mathrm{~g}$ of $\mathrm{Zn}^{0}$ had a degradation rate constant, $k$, of $0.013\left(\mathrm{~h}^{-1}\right)$ and a half-life of $56.8 \mathrm{~h}$; while the run with $5 \mathrm{~g}$ of $\mathrm{Zn}^{0}$ had a degradation rate constant, $k$, of $0.0255\left(\mathrm{~h}^{-1}\right)$ and a half-life of $35.7 \mathrm{~h}$. The rela-

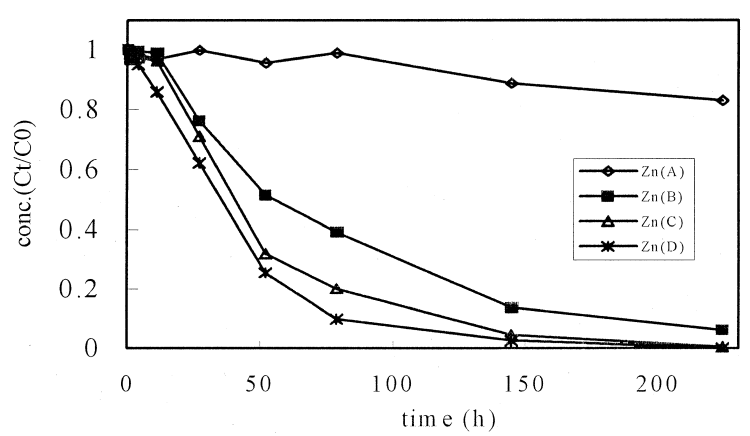

Fig. 2. TCE degradation by using $\mathrm{Zn}^{0}$. Conditions: batch tests were performed by using different mass and sources of $\mathrm{Zn}^{0}$ in serum vials $\left(15 \mathrm{ml}\right.$ by volume) in contact with $3 \mathrm{mg}$ TCE $1^{-1}$ solution at $25^{\circ} \mathrm{C}, 130 \mathrm{rpm}$. Curve $\mathrm{Zn}(\mathrm{A})$ : Acros, granular, $3 \mathrm{~g}$. Curve $\mathrm{Zn}(\mathrm{B})$ and $\mathrm{Zn}(\mathrm{C})$ : Aldrich, granular. $\mathrm{Zn}(\mathrm{B}): 3 \mathrm{~g} ; \mathrm{Zn}(\mathrm{C})$ : 5 g. Curve $\mathrm{Zn}(\mathrm{D})$ : Hanawa, powdered, $3 \mathrm{~g}$. 
Table 1

The half-lives $\left(t_{1 / 2}\right.$, for $3 \mathrm{mg}$ TCE $\left.1^{-1}, 15 \mathrm{ml}\right)$ for TCE degradation by $\mathrm{Fe}^{0}, \mathrm{Zn}^{0}, \mathrm{Ni}^{0}$ and bimetallics

\begin{tabular}{|c|c|}
\hline Materials & $t_{1 / 2}(\mathrm{~h})$ \\
\hline Riedel powdered $\mathrm{Fe}^{0}(3 \mathrm{~g})$ & 2589 \\
\hline Aldrich granular $\mathrm{Fe}^{0}(3 \mathrm{~g})$ & 239 \\
\hline Hanawa powdered $\mathrm{Zn}^{0}(3 \mathrm{~g})$ & 26.8 \\
\hline Acros granular $\mathrm{Zn}^{0}(3 \mathrm{~g})$ & 716 \\
\hline Aldrich granular $\mathrm{Zn}^{0}(3 \mathrm{~g})$ & 56.8 \\
\hline Aldrich granular $\mathrm{Zn}^{0}(5 \mathrm{~g})$ & 35.7 \\
\hline Aldrich powdered $\mathrm{Ni}^{0}(3 \mathrm{~g})$ & 1226 \\
\hline $\begin{array}{l}\text { Riedel powdered } \mathrm{Fe}^{0}(3 \mathrm{~g}) / \text { Aldrich powdered } \\
\mathrm{Ni}^{0}(3 \mathrm{~g})\end{array}$ & 14.3 \\
\hline $\begin{array}{l}\text { Aldrich granular } \mathrm{Fe}^{0}(3 \mathrm{~g}) / \text { Aldrich powdered } \\
\mathrm{Ni}^{0}(3 \mathrm{~g})\end{array}$ & $3.9-5.0$ \\
\hline $\begin{array}{l}\text { Riedel powdered } \mathrm{Fe}^{0}(3 \mathrm{~g}) / \text { Acros powdered } \\
\operatorname{Pd}^{0}(50 \mathrm{mg})\end{array}$ & 32.8 \\
\hline $\begin{array}{l}\text { Aldrich granular } \mathrm{Fe}^{0}(3 \mathrm{~g}) / \text { Acros powdered } \\
\mathrm{Pd}^{0}(50 \mathrm{mg})\end{array}$ & 1.3 \\
\hline $\begin{array}{l}\text { Riedel powdered } \mathrm{Fe}^{0}(3 \mathrm{~g}) / \text { Aldrich granular } \\
\mathrm{Zn}^{0}(3 \mathrm{~g})\end{array}$ & 84.1 \\
\hline $\begin{array}{l}\text { Hanawa powdered } \mathrm{Zn}^{0}(3 \mathrm{~g}) / \text { Aldrich pow- } \\
\text { dered } \mathrm{Ni}^{0}(3 \mathrm{~g})\end{array}$ & 0.86 \\
\hline $\begin{array}{l}\text { Aldrich granular } \mathrm{Zn}^{0}(3 \mathrm{~g}) / \text { Aldrich powdered } \\
\mathrm{Ni}^{0}(3 \mathrm{~g})\end{array}$ & 1.69 \\
\hline $\begin{array}{l}\text { Acros granular } \mathrm{Zn}^{0}(3 \mathrm{~g}) / \text { Aldrich powdered } \\
\mathrm{Ni}^{0}(3 \mathrm{~g})\end{array}$ & 0.98 \\
\hline $\begin{array}{l}\text { Acros granular } \mathrm{Zn}^{0}(3 \mathrm{~g}) / \text { Acros powdered } \\
\mathrm{Pd}^{0}(50 \mathrm{mg})\end{array}$ & 0.46 \\
\hline
\end{tabular}

tionship between the degradation rate of TCE and the amount of addition of $\mathrm{Zn}^{0}$, within the scope of this study, seemed to be in a proportional relationship.

The comparison results in the system of this research indicated that the degradating rate of $\mathrm{Zn}^{0}$ to TCE was much faster than that of $\mathrm{Fe}^{0}$ under the same reaction conditions. There can be a difference of nearly 10 times between TCE half-lives. The research results also indicated that the method of using $\mathrm{Zn}^{0}$ to decompose TCE was quite an effective method. In the future, studies can be carried out to further investigate the degradation process of $\mathrm{Zn}^{0}$ on chlorinated organic compounds in order to evaluate the feasibility of using it to replace $\mathrm{Fe}^{0}$.

\section{The promotional effects of bimetallics on TCE degra- dation}

\subsection{The promotional effects of $\mathrm{Pd}^{0}$ and $\mathrm{Ni}^{0}$ on degrada- tion of TCE by $\mathrm{Fe}^{0}$}

This research first investigated the effects of combining $\mathrm{Fe}^{0}$ with a second metal of $\mathrm{Ni}^{0}$ or $\mathrm{Pd}^{0}$ on the reaction rate of decomposing TCE. The research results indicated that $\mathrm{Ni}^{0}$ and $\mathrm{Pd}^{0}$ all have a rather strong promotional effect on the degradation reaction of TCE by $\mathrm{Fe}^{0}$. The degradation reaction of TCE by using Riedel-deHaen powdered iron singly was not very significant. However, the TCE conspicuously decomposed in a linear attenuation model when Aldrich powdered $\mathrm{Ni}^{0}$ or Acros powdered $\mathrm{Pd}^{0}$ was added to the reaction system. The degradation rate of TCE by combining Riedel-deHaen powdered $\mathrm{Fe}^{0}$ with $3 \mathrm{~g}$ of $\mathrm{Ni}^{0}$ had a halflife of $14.3 \mathrm{~h}$; while by combining with $50 \mathrm{mg}$ of $\mathrm{Pd}^{0}$ the half-life was $32.8 \mathrm{~h}$. The half-life of TCE was $239 \mathrm{~h}$ for Aldrich granular $\mathrm{Fe}^{0}$ alone; it was $3.9-5 \mathrm{~h}$ for combination of the Aldrich granular $\mathrm{Fe}^{0}$ with $\mathrm{Ni}^{0}$, and $1.3 \mathrm{~h}$ for the combination of the Aldrich granular $\mathrm{Fe}^{0}$ with $\mathrm{Pd}^{0}$. Figs. 3 and 4 show the variation of TCE concentration to the reaction time in a degradation reaction system of TCE where $\mathrm{Fe}^{0}$ in conjunction with $\mathrm{Ni}^{0}$ or $\mathrm{Pd}^{0}$ was used. The degradation process of granular iron in conjunction with $\mathrm{Ni}^{0}$ approximates a linear slow attenuation model at the initial stage. After a short period of reaction, however, the degradation reaction model

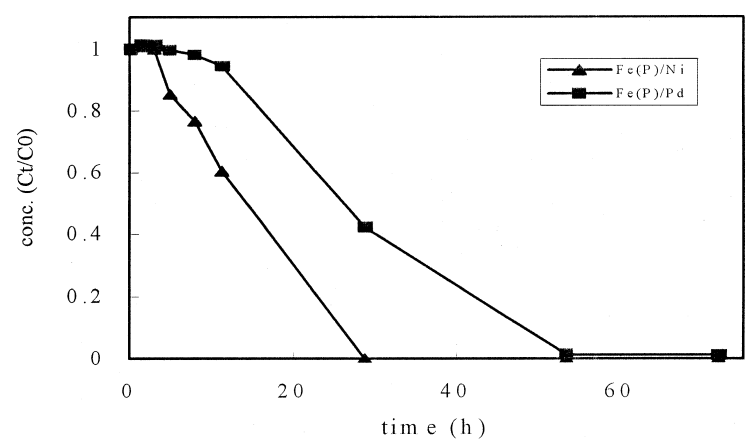

Fig. 3. TCE degradation by using powdered $\mathrm{Fe}^{0}$ combination with $\mathrm{Pd}^{0}$ and $\mathrm{Ni}^{0}$. Conditions: batch tests were performed in

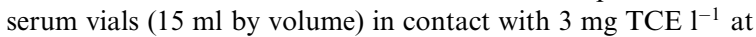
$25^{\circ} \mathrm{C}, 130 \mathrm{rpm}$. Curve $\mathrm{Fe}(\mathrm{P}) / \mathrm{Pd}$ used $3 \mathrm{~g}$ of $\mathrm{Fe}^{0}$ and $50 \mathrm{mg}$ of $\mathrm{Pd}^{0}$. Curve $\mathrm{Fe}(\mathrm{P}) / \mathrm{Ni}$ used $3 \mathrm{~g}$ of $\mathrm{Fe}^{0}$ and $3 \mathrm{~g}$ of $\mathrm{Ni}^{0}$.

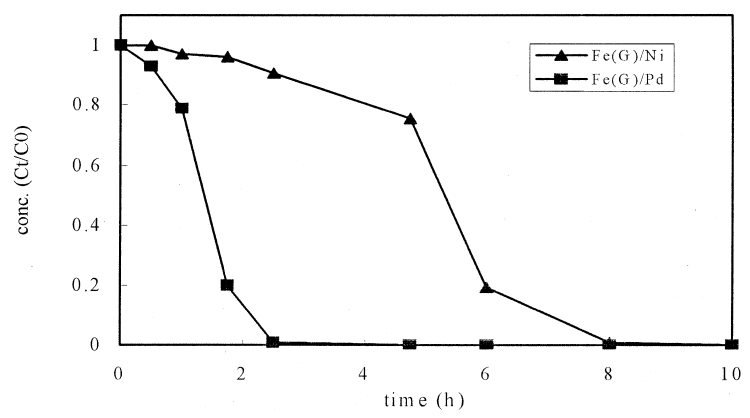

Fig. 4. TCE degradation by using granular $\mathrm{Fe}^{0}$ combination with $\mathrm{Pd}^{0}$ and $\mathrm{Ni}^{0}$. Conditions: batch tests were performed in

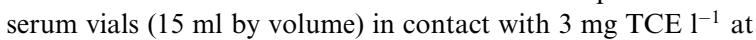
$25^{\circ} \mathrm{C}, 130 \mathrm{rpm}$. Curve $\mathrm{Fe}(\mathrm{G}) / \mathrm{Pd}$ used $3 \mathrm{~g}$ of $\mathrm{Fe}^{0}$ and $50 \mathrm{mg}$ of $\mathrm{Pd}^{0}$. Curve $\mathrm{Fe}(\mathrm{G}) / \mathrm{Ni}$ used $3 \mathrm{~g}$ of $\mathrm{Fe}^{0}$ and $3 \mathrm{~g}$ of $\mathrm{Ni}^{0}$. 
approximates a logarithmic rapid attenuation model. It can be assumed that the reaction rate at the initial stage was predominantly controlled by the transport mechanism (Burris et al., 1995; Scherer et al., 1997).

The addition of $\mathrm{Pd}^{0}$ or $\mathrm{Ni}^{0}$ does indeed have a significant promotional effect on the degradation of TCE by $\mathrm{Fe}^{0}$. In particular, the addition of $\mathrm{Pd}^{0}$ or $\mathrm{Ni}^{0}$ has a reviving effect on iron that has lost the surface activities thereof.

\subsection{The promotional effects of $P d^{0}$ and $N i^{0}$ on degrada- tion of TCE by $\mathrm{Zn}^{0}$}

This research also tried to combine $\mathrm{Zn}^{0}$ with a second metal of $\mathrm{Ni}^{0}$ or $\mathrm{Pd}^{0}$ in the degradation reaction of TCE in order to understand the promotional effect of $\mathrm{Ni}^{0}$ or $\mathrm{Pd}^{0}$ on the degradation of TCE by $\mathrm{Zn}^{0}$. The research results indicated that the addition of $\mathrm{Ni}^{0}$ or $\mathrm{Pd}^{0}$ rapidly increased the degradation reaction rate of TCE by $\mathrm{Zn}^{0}$. When $\mathrm{Ni}^{0}$ was added, the half-life of the reaction system could be reduced to about $3 \%$ of that of the reaction system where $\mathrm{Zn}^{0}$ was used singly. The half-life by the Hanawa powdered $\mathrm{Zn}^{0}$ was $26.8 \mathrm{~h}$, which fell to $0.86 \mathrm{~h}$ after combining with $\mathrm{Ni}^{0}$. The half-life by the Aldrich granular $\mathrm{Zn}^{0}$ was $56.8 \mathrm{~h}$, which fell to $1.69 \mathrm{~h}$ after combining with $\mathrm{Ni}^{0}$. The effects were even more significant for the Acros granular $\mathrm{Zn}^{0}$ that had a weaker reactivity. When the Acros $\mathrm{Zn}^{0}$ was used singly, the nondecomposed TCE concentration remained larger than $80 \%$ after a reaction time of $237 \mathrm{~h}$. The half-life fell to less than $1 \mathrm{~h}$ when $\mathrm{Ni}^{0}$ was added. The reaction rate increased even further when $\mathrm{Pd}^{0}$ was added. The half-life of a degradation reaction where the Aldrich granular $\mathrm{Zn}^{0}$ was used in conjunction with $\mathrm{Pd}^{0}$ was 0.46 h. Fig. 5 shows the degradation reaction curve of TCE when $\mathrm{Zn}^{0}$ was used in conjunction with $\mathrm{Ni}^{0}$, and Fig. 6 for $\mathrm{Pd}^{0}$. Fig. 5 clearly indicated that the degradation reaction of

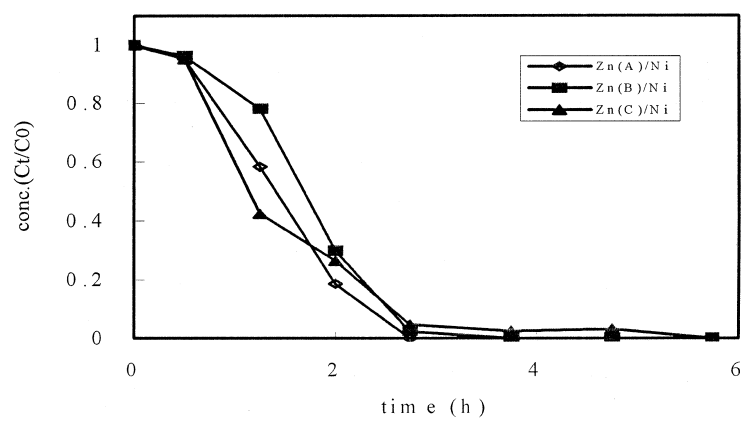

Fig. 5. TCE degradation by using different $\mathrm{Zn}^{0}$ combination with $\mathrm{Ni}^{0}$. Conditions: batch tests were performed by using $3 \mathrm{~g}$ of $\mathrm{Zn}^{0}$ and $3 \mathrm{~g}$ of $\mathrm{Ni}^{0}$ in serum vials $(15 \mathrm{ml}$ by volume) in contact with $3 \mathrm{mg} \mathrm{TCE} 1^{-1}$ at $25^{\circ} \mathrm{C}, 130 \mathrm{rpm}$. $\mathrm{Zn}(\mathrm{A})$ : Hanawa powdered $\mathrm{Zn}, \mathrm{Zn}(\mathrm{B})$ : Aldrich granular $\mathrm{Zn}, \mathrm{Zn}(\mathrm{C})$ : Acros granular $\mathrm{Zn}$.

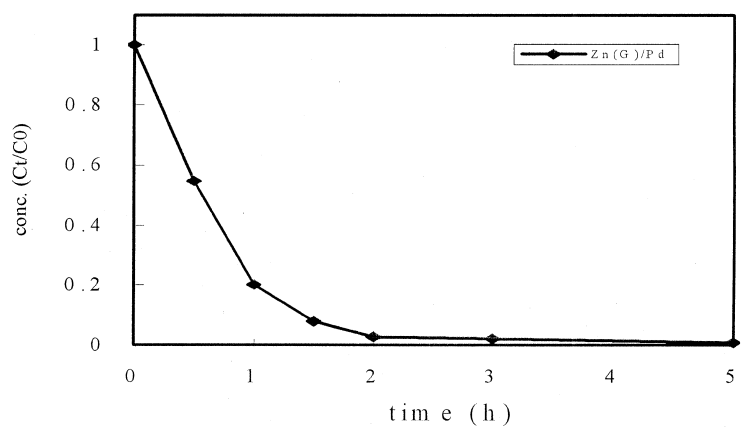

Fig. 6. TCE degradation by using $\mathrm{Zn}^{0}$ combination with $\mathrm{Pd}^{0}$. Conditions: batch tests were performed by using $3 \mathrm{~g}$ of $\mathrm{Zn}^{0}$ and $50 \mathrm{mg}$ of $\mathrm{Pd}^{0}$ in serum vials ( $15 \mathrm{ml}$ by volume) in contact with $3 \mathrm{mg} \mathrm{TCE} 1^{-1}$ at $25^{\circ} \mathrm{C}, 130 \mathrm{rpm}$. $\mathrm{Zn}(\mathrm{G})$ was obtained from Aldrich granular $\mathrm{Zn}$.

TCE exhibited a stagnation phenomenon after the reaction at the initial stage of the reaction, then rapidly attenuated exponentially. It was inferred that the reaction rate was predominantly controlled by the transport mechanism during the initial stage of the reaction (Burris et al., 1995; Scherer et al., 1997).

The bimetallics formed by $\mathrm{Zn}^{0}$ or $\mathrm{Fe}^{0}$ in conjunction with $\mathrm{Ni}^{0}$ or $\mathrm{Pd}^{0}$ did indeed have a tremendous promotional effect on the degradation reactions of TCE. Moreover, another characteristic of the bimetallics to the degradation reaction of TCE was that from our analysis result there was almost no formation of any chlorinated organic intermediate during the entire reaction process.

\section{Conclusions}

The results of this research indicated that factors such as the source characteristics, the purity, etc. of $\mathrm{Fe}^{0}$, had a strong influence on the degradation rate of TCE. For $\mathrm{Fe}^{0}$ of different sources, the reaction rates thereof could vary by up to three orders of magnitude. Furthermore, the storage of $\mathrm{Fe}^{0}$ was another troublesome factor. Therefore, care must be taken in selecting zerovalent iron in the remediation technique.

In both electrochemical theory and the findings in the actual experiments, $\mathrm{Zn}^{0}$ appeared far more suitable for the degradation of the chlorinated organic compounds than $\mathrm{Fe}^{0}$ did. $\mathrm{Zn}^{0}$ had a faster degradating rate to the chlorinated organic compounds. The half-life of TCE with $\mathrm{Zn}^{0}$ was only one-tenth to that with $\mathrm{Fe}^{0}$. The storage of $\mathrm{Zn}^{0}$ was also easier than that of $\mathrm{Fe}^{0}$. Even though a long period had elapsed since it was unsealed, a strong reactivity was still retained. Moreover, $\mathrm{Zn}^{0}$ is an indispensable trace element required by the human body. The tolerable concentration thereof in the drink- 
ing water is rather high $(5 \mathrm{mg} / \mathrm{l})$. Therefore, the evaluation of the use of $\mathrm{Zn}^{0}$ replacing $\mathrm{Fe}^{0}$ in the techniques of remediation of groundwater contaminated by chlorinated organic compounds deserves further study.

The combinations of $\mathrm{Zn}^{0}$ or $\mathrm{Fe}^{0}$ with $\mathrm{Ni}^{0}$ or $\mathrm{Pd}^{0}$ did indeed have strong promotional effects on the degradation reactions of TCE. The half-life of $\mathrm{Fe}^{0} / \mathrm{Ni}^{0}$ could be reduced to 3.9-5 h; the half-life of $\mathrm{Fe}^{0} / \mathrm{Pd}^{0}$ could be reduced to $1.3 \mathrm{~h}$, the half-life of $\mathrm{Zn}^{0} / \mathrm{Ni}^{0}$ could be reduced to $0.86 \mathrm{~h}$, and the half-life of $\mathrm{Zn}^{0} / \mathrm{Pd}^{0}$ could be reduced to $0.46 \mathrm{~h}$. The other characteristics of the bimetallics were that $\mathrm{Fe}^{0}$ with inactive surfaces could be effectively revived and have an effective degradation on TCE. The application of the bimetallics technique enabled a substantially complete dechlorination reaction that was generally free of the formation of any chlorinated organic intermediates.

Although the combination use of $\mathrm{Pd}^{0}$ gave an optimum result, $\mathrm{Pd}^{0}$ is a precious metal and its use seems not feasible in economic terms. $\mathrm{Ni}^{0}$ would be a more appropriate choice. The research results indicated that the combination of $\mathrm{Zn}^{0}$ and $\mathrm{Ni}^{0}$ had a promotional effect nearly the same as that of the combination of $\mathrm{Zn}^{0}$ and $\mathrm{Pd}^{0}$. It should be possible for the promotional effects thereof on the degradation rate of the chlorinated organic compounds to be raised further if further studies can be carried out on the combination ratios, the combination forms, and the control of reaction conditions. Furthermore, there is no specific regulation on the tolerable concentration of nickel in the standard of water qualities. The feasibility of this technique can be further evaluated by exploring other areas including the residual concentration of nickel in the aqueous solution after reaction, the influence of nickel on the human body, and the tolerable concentration of nickel in the drinking water.

\section{Acknowledgements}

The authors gratefully acknowledge the financial support provided by the National Science Council, ROC (Contract No. NSC 88-2218-E-002-035) for this research work.

\section{References}

Agrawal, A., Tratnyek, P.G., 1996. Reduction of nitro aromatic compounds by zero-valent iron metal. Environ. Sci. Technol. 30, 153-160.

Appleton, E.L., 1996. A nickel-iron wall against contaminated groundwater. Environ. Sci. Technol. 30, 536-539.

Ballapragada, B.S., Stensel, H.D., Puhakka, J.A., Ferguson, J.F., 1997. Effect of hydrogen on reductive dechlorination of chlorinated ethenes. Environ. Sci. Technol. 31, 1728-1734.
Burris, D.R., Campbell, T.J., Manoranjan, V.S., 1995. Sorption of trichloroethylene and tetrachloroethylene in a batch reactive metallic iron-water system. Environ. Sci. Technol. 29, 2850-2855.

Cheng, S.F., Wu, S.C., 1998. Enhancing chlorinated methanes degradation by modifying the $\mathrm{Fe} 0$ reduction system. In: Physical, Chemical, and Thermal Technologies, vol. C1-5. Battelle Press, USA, pp. 299-304.

Criddle, C.S., McCarty, P.L., 1991. Electrolytic model system for reductive dehalogenation in aqueous environments. Environ. Sci. Technol. 25, 973-978.

Gavaskar, A.R., Sass, B.M., Drescher, E., Cumming, L., Giammar, D., Gupta, N., 1998. Enhancing the reactivity of permeable barrier media. In: Designing and Applying Treatment Technologies, vol. C1-6. Battelle Press, USA, pp. 91-96.

Gillham, R.W., Stephanie, F.H., 1994. Enhanced degradation of halogenated aliphatics by zero-valent iron. Ground Water 32, 958-967.

Gold, G., Angst, W., Holliger, C., Schwarzenbach, R.P., 1997. Corrinoid-mediated reduction of tetrachloroethene trichloroethene and trichlorofluoroethene in homogeneous aqueous solution: reaction kinetics and reaction mechanisms. Environ. Sci. Technol. 31, 253-260.

Matheson, L.J., Tratnyek, P.G., 1994. Reduction dehalogenation of chlorinated methanes by iron metal. Environ. Sci. Technol. 28, 2045-2053.

Muftikian, R., Fernando, Q., Korte, N., 1995. A method for the rapid dechlorination of low molecular weight chlorinated hydrocarbons in water. Wat. Res. 29, 2434-2439.

O'Hannesin, S.F., Gillham, R.W., 1998. Long-term performance of an in situ "iron wall" for remediation of VOCs. Ground Water 36, 164-170.

Orth, W.S., Gillham, R.W., 1996. Dechlorination of trichloroethene in aqueous solution using $\mathrm{Fe}^{(0)}$. Environ. Sci. Technol. 30, 66-71.

Roberts, A.L., Totten, L.A., Arnold, W.A., Burris, D.R., Campbell, T.J., 1996. Reductive elimination of chlorinated ethylenes by zero-valent metals. Environ. Sci. Technol. 30, 2654-2659.

Ruiz, N.E., Reinhart, D.R., Clausen, C.A., Geiger, C.L., Lau, N., 1998. Enhanced zero-valent iron degradation of chlorinated solvents using ultrasonic energy. In: Designing and Applying Treatment Technologies, vol. C1-6. Battelle Press, USA, pp. 71-76.

Scherer, M.M., Westall, J.C., Ziomek-Moroz, M., Tratnyek, P.G., 1997. Kinetics of carbon tetrachloride reduction at an oxide-free iron electrode. Environ. Sci. Technol. 31, 2385-2391.

Siantar, D.P., Schreier, C.G., Chou, C.S., Reinhard, M., 1996. Treatment of 1,2-dibromo-3-chloropropane and nitratecontaminated water with zero-valent iron or hydrogen/ palladium catalysis. Wat. Res. 30, 2315-2322.

Smyth, D., Cherry, J., Jowett, R., 1995. Treat groundwater in place - in situ funnel-and-gate system corrals water for treatment. Soil Groundwater Clean up, December, $36-43$.

Su, C., Puls, R.W., 1999. Kinetics of trichloroethene reduction by zerovalent iron and tin: pretreatment effect apparent activation energy, and intermediate products. Environ. Sci. Technol. 33, 163-168. 
Vogel, M.T., Criddle, C.S., McCarty, P.L., 1987. Transformations of halogenated aliphatic compounds. Environ. Sci. Technol. 21, 722-736.

Wang, C.B., Zhang, W.X., 1997. Synthesizing nanoscale iron particles for rapid and complete dechlorination of TCE and PCBs. Environ. Sci. Technol. 31, 2154-2156.
Weber, E.J., 1996. Iron-mediated reductive transformations: investigation of reaction mechanism. Environ. Sci. Technol. $30,716-719$. 